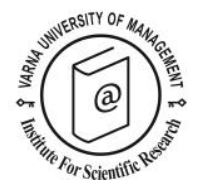

\title{
Social capital as cause and consequence of rural touristic development: The case of Lindoso (Portugal)
}

\author{
Tiago Borlido ${ }^{1 *}$ and Lluís Coromina ${ }^{2}$
}

Received: 28/07/2017 Accepted: 20/02/2018

\footnotetext{
${ }^{1}$ Faculty of Tourism, University of Girona, Girona, Spain, Plaça Josep Ferrater i Móra, 1, 17004 Girona; Tel.: +35191703 1472; email: tiago.borlido@gmail.com

2 Faculty of Tourism, University of Girona, Girona, Spain, Plaça Josep Ferrater i Móra, 1, 17004 Girona; Tel.: +34 97241 9720; email: Iluis.coromina@udg.edu

* Corresponding author
}

\begin{abstract}
This paper seeks to deepen research on the relationship established between social capital and tourism, namely on the less explored aspect of the reciprocity in this relationship; in other words, the forms by which social capital affects tourism development and how tourism development has influenced the evolution of social capital are the object of analysis. The paper uses a qualitative approach based on in-depth interviews and discourse analysis. Results show that a lack of use of social capital provokes a vicious circle of social capital destruction, meeting Putnam's (1995, 2000) theories in his magnum opus Bowling Alone. Results additionally show that social capital facilitates tourism development and, in turn, tourism development promotes the creation of bridging social capital in the community. This paper concludes presenting policy proposals that seek to lead the territory towards a more sustainable community approach to the tourism model using the existing social capital and fostering its growth.
\end{abstract}

(C) 2018 Varna University of Management. All rights reserved

Keywords: Social capital, tourism, development, sustainability, social relationships, community.

Citation: Borlido, T., L. Coromina (2018) Social capital as cause and consequence of rural touristic development: The case of Lindoso (Portugal). European Journal of Tourism Research 19, pp. 71-85

\section{Introduction}

This paper examines social capital existing in rural regions and the impact it has on the profile of tourism development therein. The concept of social capital has been presented as the "missing link" in development and has been the aim of a considerable amount of research, especially since Putnam (1995, 2000) published his magnum opus 'Bowling Alone', popularizing the concept (Fernandes, 2009; Jones, 2005). Its importance has been proven in areas as varied as human capital creation, innovation, sustainable development, economic growth, democracy, poverty reduction or environmental sustainability (Coleman, 2000b; Elche-Hortelano, Martínez-Pérez, \& GarcíaVillaverde, 2015; Fernandes, 2009; Jones, 2005; Martínez-Pérez, García-Villaverde, \& 
Elche, 2016; Putnam, 1993). The core idea of social capital - that social relationships have value, as they promote cooperation towards common goals - is therefore valid in a multitude of contexts, and tourism is no exception (Jones, 2005). Why is it, then, that the association between these two fields has yet to be studied in depth?

In effect, research on the theme is still in an incipient phase. Nevertheless, interest on connecting these two fields has grown over the last decade, with several authors analysing the theme and progressively contributing to the establishment of social capital as an essential ingredient of sustainable tourism development (Bennett, Lemelin, Koster, \& Budke, 2012; Fernandes, 2009; Gibson et al., 2014; Mbaiwa \& Stronza, 2010; McGehee, Lee, O'Bannon, \& Perdue, 2010; Park, Lee, Choi, \& Yoon, 2012; Zahra \& McGehee, 2013; Zhao, Ritchie, \& Echtner, 2011). Nevertheless, only a scarce amount of papers and academic studies that connect the two themes can be found - the concept of social capital is not yet firmly rooted in tourism literature. While its importance has obtained some acceptance with tourism academics, there is still a need for a better understanding of the intricacies of social capital functioning and of how it can foster the growth of the tourism industry.

Reverse causality is one of the often overlooked aspects of this relationship: social capital affects tourism development, but the opposite also happens, generating a virtuous/vicious circle. This is far less studied (Mansuri \& Rao, 2004; Portes, 1998), and is also analysed in this paper. In effect, the number of articles that analyse reverse causality in a tourism context is very reduced (Gibson et al., 2014; Jones, 2005; Mbaiwa \& Stronza, 2010; McGehee et al., 2010; Zahra \& McGehee, 2013), considering the major impacts tourism has on the society and on the relationships between human beings. Studying this matter has, then, great pertinence, not only to further knowledge on this causal relationship, but also to determine ways through which tourism can bring more benefits to the community in terms of social capital.
It was thus established as the main aim of this research the ascertainment of which kind of relationship exists between social capital of a certain rural territory and tourism development in that same territory. A secondary aim is to propose practical ways by which this relationship can be explored and used to promote tourism development and the community's wellbeing.

From this main objective a research question was formulated: "What relationship exists between touristic development in a given rural territory and the existing social capital?" The first section of this article seeks possible answers to this question in a literature review on the studied fields. Basing ourselves on the role of tourism development in overcoming the specific challenges rural areas face, a discussion is established on the importance of social capital for the development of a sustainable tourism model that brings benefits to the rural populations. The following section presents the methodology used to conduct this study; in it, the used qualitative approach is explained, as well as the techniques utilized for compiling information. The third section introduces the studied area with a brief characterization of the territory of Lindoso.

The fourth section presents the results of the field work, in terms of cognitive and structural social capital. The main trends drawn from the interviews that were conducted with the different stakeholders are presented as well as quotes relevant to the matter. Finally, conclusions of the paper and possible policies for fomenting development in the area and for promoting the population's life quality are presented.

Before approaching the issue of tourism, however, the specificities of rural territories will be used as a starting point for the analysis established in the literature review of the folowing section.

\section{Literature review}

\section{Rural tourism and social capital}

The economic development of rural areas faces obstacles that are specific to them. One of the main hindrances is population decrease and ageing, which has aggravated over the last 
decades and is responsible for a lack of agents and promotors that can trigger the process of economic development (Galvão \& DevyVareta, 2010; Nunes, Lourenço, BentoGonçalves, \& Vieira, 2013; Silva, 2007; Terres, Nisini, \& Anguiano, 2013). Small-scale agriculture, of great importance for rural economy and society, suffers from a decrease of economic viability, and the population's low education level, associated with the lack of knowledge centres that can provide instruction, means there are few employment alternatives for the inhabitants of these areas (Cavaco, 2004; Fortescu, 2016; Muilu, Gilbert, Phimister, \& Shucksmith, 2017; Silva, 2007; Terres et al., 2013). The situation is worsened by the weak business and institutional structure, by low investment attractiveness and by the service and infrastructure deficit, characteristic of these areas (Pato, Breda, Cunha, \& Kastenholz, 2014; Silva, 2007). This conjuncture exacerbates rural exodus and consequently provokes a loss of self-esteem and sense of belonging, as well as an identity crisis, on those who are left behind (Cavaco, 2004; Cruz, 2016). Rural areas suffer, therefore, serious challenges on socioeconomic terms.

Nevertheless, rural areas also possess characteristics, such as rural landscape, conditions for the practice of nature sports, tranquillity, peace, or cultural heritage, that serve as strong tourist assets, leading to the rise of rural tourism (Galvão \& Devy-Vareta, 2010; Huang, Beeco, Hallo, \& Norman, 2016; Mclntyre, 1993; Negi, 1990). Rural tourism can be loosely defined as all tourist activity that takes place in a rural area (Keane, 2000). Lane (as quoted by Figueiredo, Eusébio, \& Breda, 2016) specifies further by saying that ideally rural tourism should be located in rural areas, functionally rural, rural in scale, traditional in character, organically and slowly growing and controlled by local communities. Lane, by defining rural tourism, additionally gives his opinion on how rural tourism development should occur.

Lane's ideas can be inserted in the sustainable development concept that was put forward with the Brundtland Report. According to this report, sustainable development should be defined as 'a process of change in which the exploitation of resources, the direction of investments, the orientation of technological development; and institutional change are all in harmony and enhance both current and future potential to meet human needs and aspirations' (World Commission on Environment and Development, 1987 : 43).

This type of tourism development has the potential to trigger a rural area revitalization process through the multiplier effect that it generates, promoting economic development, employment creation and the generation of supplementary income, and stopping or even inverting the population decrease problem (Breda, Costa, \& Costa, 2006; Fernandes, 2009; Kastenholz \& Sparrer, 2009; McIntyre, 1993; Möller \& Amcoff, 2016; Negi, 1990). It can additionally contribute to the conservation of natural and cultural heritage and to increasing the population's life quality, consequently encouraging it to stay in the zone (Fortescu, 2016; Mclntyre, 1993; Page \& Getz, 1997).

If carefully planned tourism can, thus, promote life quality, generating economic, social and cultural benefits - in effect this is, according to McCool \& Martin (1994), the main objective of tourism development. However, several are the cases in which this scenario does not occur, with rural tourism models that distance themselves from the population and bring it reduced benefits (Fernandes, 2009; Kastenholz \& Sparrer, 2009; Park et al., 2012; Pongponrat \& Chantradoan, 2012; Ribeiro \& Marques, 2002). In this context, the concept of integrated rural tourism that was presented by Saxena, Clark, Oliver, \& Ilbery (2007) is of particular importance, referring to "tourism explicitly linked to the economic, social, cultural, natural and human structures of the localities in which it takes place". Forged through the construction of formal and informal networks that stimulate local coordination and integration, this model seeks sustainable tourism development with long term benefits (Saxena et al., 2007 :347).

These models defend an endogenous approach that implies community participation and empowerment, while also demanding an organizational structure that promotes coordination in the community (Fernandes, 
Social capital as cause and consequence of rural touristic development: The case of Lindoso (Portugal).

2009). These have obtained increasing popularity among tourism academics only in the last decades - however, the importance of networks for economic development in general is not a new idea; in fact, these ideas can be inserted in the concept of social capital, used for the first time in 1916 by Hanifan (Boutilier, 2017; Fernandes, 2009; Hanifan, 1916; Woolcock \& Narayan, 2000).

Bourdieu (1980) is one of the most prominent authors in social capital literature, describing the concept as the sum of actual or potential resources related with the possession of a durable network of more or less institutionalized relationships of mutual acquaintance and recognition (Bourdieu, 1980; Portes, 1998).

It is, however, Putnam's work the one that has been more publicized and that is responsible for the popularity of the concept nowadays (Boutilier, 2017; Field, 2008). This author develops it further, presenting social capital as the '(...) features of social organization such as networks, norms, and social trust that facilitate coordination and cooperation for mutual benefit' (Putnam, 1995, p. 2).

Coleman (2000a, 2000b), on the other hand, understands social capital not as a single entity, but as a variety of different entities, that share two common elements: all are constituted by some aspect of social structures and all facilitate certain actions by agents inside those social structures.

Summarizing the contributions of several authors, Jones (2005) states that 'social networks have value, as interaction and connections develop shared norms, trust, and reciprocity that in turn foster cooperation to achieve common ends' (p. 306). Social capital would refer, therefore, 'to the degree of connectedness and the quality and quantity of social relations in a given population or the social relations that lead to constructive outcomes for a group' (Bankstone \& Zhou, 2002; Ecclestone \& Field, 2003; Harpham, Grant \& Thomas, 2002, as quoted by Jones, 2005, p. 306).
Social relationships create value through reciprocity, which is closely connected to trust (Field, 2008; Portes, 1998; Uphoff, 2000 quoting Fukuyama, 1995); without trust, cooperation is severely hampered, since no expectation of reciprocity exists (Field, 2008). It is, then, reciprocity that, present in different types of exchanges, unites society in every aspect, producing common norms, a common identity, trust and solidarity, as well as strong economic bonds (Fernandes, 2009). For this reason, social networks with high levels of trust work better in terms of cooperation than networks with low levels of trust (Field, 2008).

\section{Development of research hypotheses}

Based on the mentioned authors, the following research hypothesis was formulated:

\section{H1. The existence of social capital promotes rural tourism development.}

What is frequently omitted is that social relationships do not necessarily lead to positive effects and may, in some cases, contribute to exclusion and social inequity, as well as discrimination, political corruption and gender inequality (Arrow, 2000; Field, 2008; Pillai, Hodgkinson, Kalyanaram, \& Nair, 2017; Putnam, 2000; Rebelo, 2012; Woolcock \& Narayan, 2000). Field (2008) explores social capital in depth, examining the role it can have in cases of social inequity and exclusion, as well as in situations of discrimination, political corruption and gender inequality. Ostrom (2000) illustrates this fact with the example of some authoritarian governments which, based on their military forces and on the use of instruments of force, construct social capital that is useful to their ends while destroying other forms of it. The negative effects of social capital are associated by some authors to bonding social capital, which can create a tendency to trust the member of one's own group excluding everyone else (Field, 2008; Pillai et al., 2017).

These negative effects can thus be associated with the forms of social capital identified by Putnam (2000): bonding and bridging social capital. Bonding social capital is introspective and tends to reinforce exclusive identities and homogeneous groups. Bridging social capital, 
on the other hand, is outward looking and refers to networks that include people across diverse social cleavages.

However, authors such as Uphoff (2000) and Krishna \& Shrader (2000) adopt a different way of categorizing social capital, differentiating between cognitive and structural social capital. According to these authors, while the first creates a predisposition for mutually beneficial collective action, the latter facilitates such actions.

Cognitive social capital would refer to attributes derived from mental processes and resulting ideas, reinforced by culture and ideology: social norms, behaviour, attitudes or values (such as trust, solidarity or reciprocity), for example. Structural social capital, on the other hand, is related to various forms of social organization, such as the organizational structure of a community, the decision-making and leadership processes or practices of collective action and responsibility (Krishna \& Shrader, 2000; Uphoff, 2000).

These elements, despite their differences, are interdependent, since they each contribute to the development of the other. Both affect behaviour through experience and are reinforced by culture, Zeitgeist and other influences (Krishna \& Shrader, 2000; Uphoff, 2000).

Literature on social capital also tends, as mentioned by authors such as Mansuri \& Rao (2004), Durlauf (2002) or Portes (1998), to ignore reverse causality, that is, the impact development may have in social capital. This is precisely one of the questions this paper intends to study, exploring the reciprocity of two aspects of causality in the relationship between social capital and development. The following research hypothesis was, therefore, identified:

\section{H2. Tourism development in a rural territory promotes the development of social capital.}

A circle is, then, formed between social capital and tourism development, as can be seen in Figure 1. This is due to social capital being a 'moral resource', according to Putnam (1993): resources whose supply increases with use and decreases without it. For this reason, its creation and destruction imply, respectively, virtuous and vicious circles. It is based on this circle that the hypotheses for this paper have been identified.

\section{Introduction to the studied area}

The analysis of a rural area has the advantage

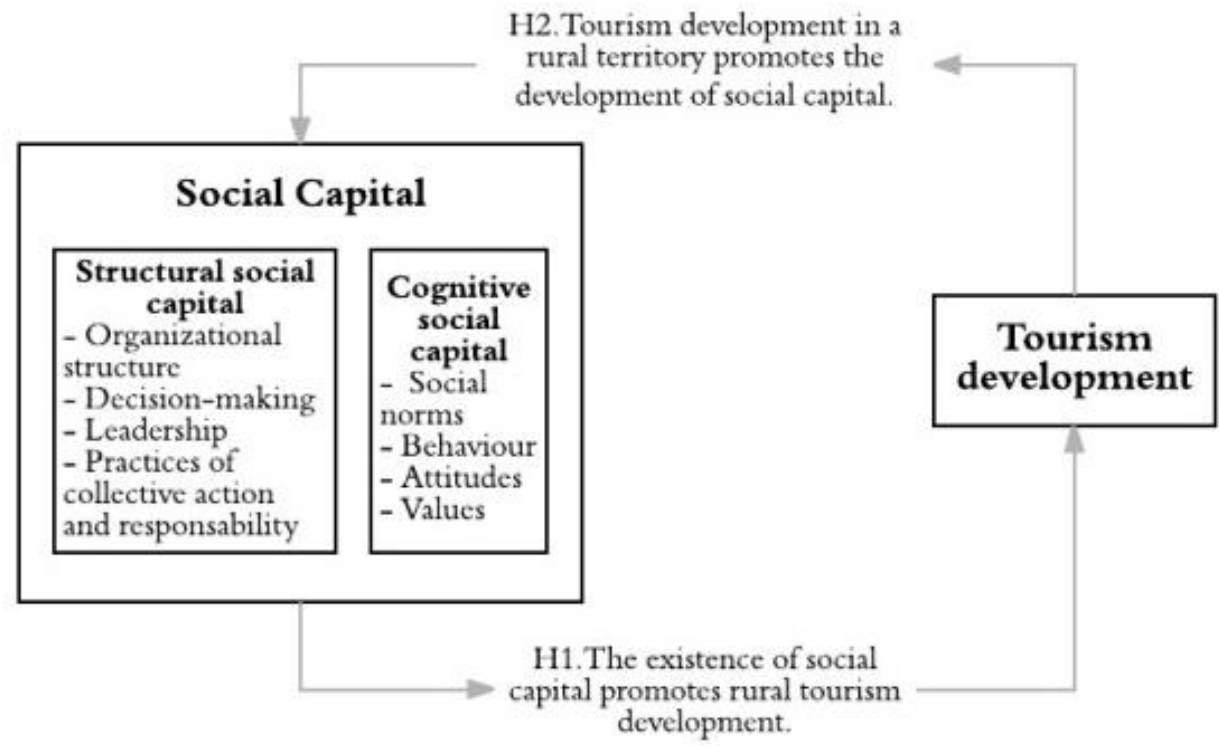

Figure 1. Social capital as a moral resource - a virtuous circle is formed between it and tourism development 
of greater transparency and stability of social structure, facilitating the analysis of social capital (Zhao et al., 2011). The territory of Lindoso, in northern Portugal, is the perfect example of this and possesses, additionally, specific characteristics that make it an especially interesting study case for social capital - namely, the traditions of communitarian agriculture present in the region. For this reason, it was chosen as the case study for this paper.

Lindoso belongs, administratively, to the municipality of Ponte da Barca. In turn, this municipality is part of the NUTS III Alto Minho, which is integrated in the NUTS II North (Fundação Francisco Manuel dos Santos, n.d.). The territory's reduced population is divided into three population nuclei, as can be seen in Figure 2: Lindoso/Real (also denominated Castelo), Parada and Cidadelhe (Fontes, 2011). At a total of 427 inhabitants, Lindoso registers very high ageing indexes and repulsive migratory flows, leading to population decrease in the last decades (Fontes, 2011; Instituto Nacional de Estatística, 2014).

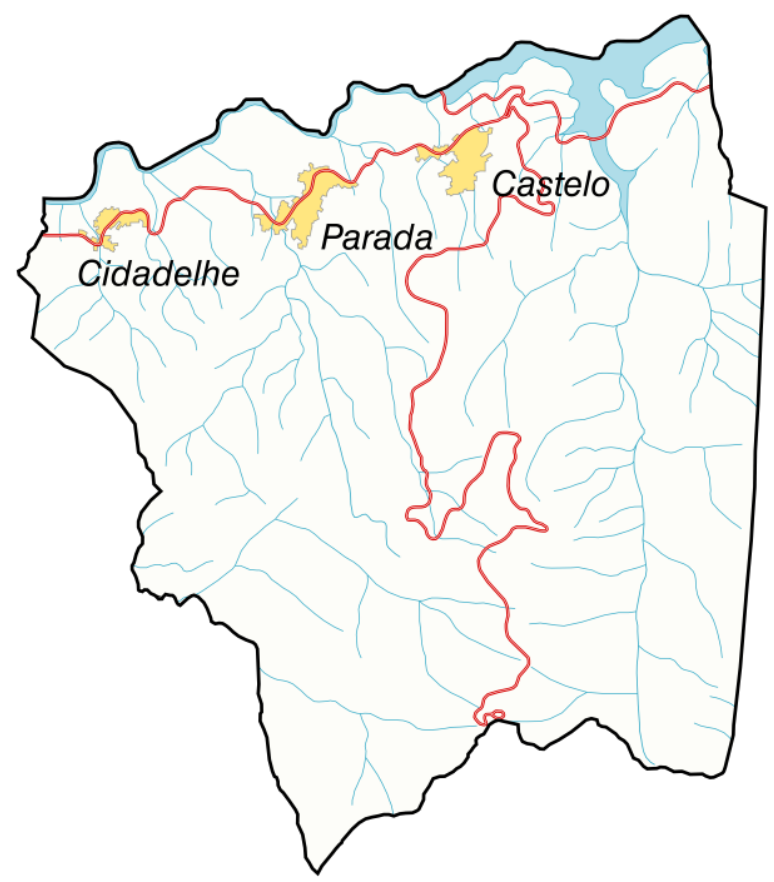

Figure 2. Map of the territory of Lindoso (adapted from Direção-Geral do Território, 2015 by Sérgio Costa)
Lindoso is a freguesia, an inframunicipal administrative division that possesses autonomous administrative bodies: a deliberative body (the Freguesia Assembly, which in some cases of freguesias with a reduced population, as is the case in Lindoso, can be substituted by the totality of electing citizens) and an executive body (the Freguesia Council). These are, nevertheless, subject to the administrative bodies that govern the municipality of Ponte da Barca (Constituição da República Portuguesa; Direção-Geral do Território, s. f.).

As a result of its rich history, Lindoso houses an important built cultural heritage, as well as an unique intangible cultural heritage, in which the already mentioned communitarian agriculture is especially relevant (Central Nacional do Turismo em Espaço Rural, 2012; Fernandes, Matos, \& Brysch, 2002; Fontes, 2011). It is furthermore located in a natural and scenic context of great value, forming part of the Peneda-Gerês National Park (Fontes, 2011). For these reasons, the village is currently visited by thousands of people every year, with over 14000 visitors being registered in 2015 at the national park's information point in the village.

\section{Methodology \\ Sampling}

Snowball sampling, a method through which the interviewees suggest other individuals in the community whose contribute would be important for the research (Karlsson, 2005), was used. An initial group of five individuals was elected to be interviewed, being chosen considering their relevance for the touristic sector. The five initial individuals were the president of a local social, cultural and sports association, the president of the Freguesia Council, the head of the National Park Tourist Information Point in the village, an academic from the village with a $\mathrm{PhD}$ thesis on associativism and social capital, and an employee of the municipality's tourism department.

The group of interviewees was then progressively broadened to include all the proprietaries of tourism houses and restaurants in the territory, the mentioned academic, the 
employee of the municipality, the head of the information point, the president of the Freguesia Council, the president of the aforementioned association and the director of a territorial development association. In total, 14 interviews were carried out between March and May 2016, both in Lindoso and in nearing settlements, and all tourism supply stakeholders in the territory were interviewed.

Five of the interviewees were approached regarding the nucleus of Castelo, of which three were tourism house owners and two restaurant owners. All lived in Castelo, except for one of the tourism house owners. Regarding the nucleus of Parada, there were also five interviews conducted, of which three were done to tourism house owners, one to the mentioned academic and one to the president of the social, cultural and sports association. Of these five interviewees, only one of the tourism house owners did not live in Parada. The remaining four interviews were done to individuals which applied to the territorial circumscription of both Parada and Castelo: the president of the Freguesia Council, the head of the National Park's tourism office at Lindoso, the president of the ADERE-PG regional development association and a representative of the Ponte da Barca Municipal Council. Of these, only the president of the Freguesia Council lived in Lindoso, namely in Parada.

The settlement of Cidadelhe was excluded from this research, which only analyses Castelo and Parada. This is due to the practically non-existent tourism development in the village, and to the consequent inexistence of tourism houses, working associations or other type of tourism agents that could be the subject to an interview.

\section{Measurement instrument}

In order to determine what kind of relationship exists between social capital and rural tourism development, instead of simply measuring the existing social capital, a measurement of the interviewees' perceptions on the existence of that type of capital was conducted, since it was considered that these measures have more value for measuring social capital (McGehee et al., 2010).
The first step of this research was an analysis of the study case's context, presented in the former section, to determine which would be the most adequate method. Considering the specific context, a methodology based on the evaluation of cognitive and structural factors was chosen (Krishna \& Shrader, 2000; Uphoff, 2000). The different forms of social capital mentioned by Bain \& Hicks (quoted by Krishna \& Shrader, 2000) were, then, incorporated in the research and analysed.

A qualitative approach was deemed the most appropriated to investigate these two dimensions of social capital, with semi structured in-depth interviews being used for data compilation. This technique was considered the most appropriate to measure the perceptions of existing social capital, as it is especially adequate for a study of this type (Quivy \& Campenhoudt, 2013).

For the interviews, a base guideline was created, which was adapted according to the specificities of each interviewee. The guideline includes a series of topics to be approached during the interview and was built based on the questionnaire used by Jones (2005) for the analysis of a community ecotourism venture in Gambia. The model for social capital measurement created by Krishna \& Shrader (2000) and the interview model used by Fernandes (2009) for the study of associativism in the Peneda-Gerês National Park were also important references. Interviewees were questioned regarding their perceptions on trust and mutual help levels in the villages, on conflict between the inhabitants, on the strength of associativism in the region, on leadership and decision-making processes in the villages, on collective action in Lindoso and on how tourism had an influence on these matters, among other themes that were considered relevant for the research.

Data analysis was done through the use of NVIVO 11. The 14 interviews were codified as cases and each case was classified according to the village to which the interviewee was associated, to the frequency of visit to the village and to the occupation of the agent. A discourse analysis was then conducted, based on 8 nodes. Of these, three relate to structural 
Social capital as cause and consequence of rural touristic development: The case of Lindoso (Portugal).

capital (participation in collective action, associativism and leadership/decision-making processes) and one to cognitive social capital (trust and mutual help), while the four remaining nodes (tourism benefits, reverse causality, tourism detriments and touristresident relationship) relate to the relationship established between social capital and tourism. All the aformentioned nodes were based off the main topics of the interview guideline, and were therefore identified based on the articles that were used as a base for its construction.

\section{Results}

\section{Cognitive social capital}

One of the things that first became evident was that the three population nuclei possessed an autonomous nature, functioning as independent villages, each with its own social dynamics and organization. In effect, there is even a feeling of rivalry and competition between the inhabitants of each of the settlements that make up the freguesia. This is evident, for example, in the association's activities (which will be discussed further ahead): when a traditional activity such as the malhada (a traditional agricultural activity in which corn mazes are hit with malhos) is organized by the cultural association of one of the villages, the other village organizes another malhada for the same day and both compete to have the best one.

Nevertheless, although trust does not exist between the three villages, the same cannot be said about the population inside each of the settlements. In fact, in Parada, the vast majority of the interviewees described a climate of trust and mutual aid, and even though in Castelo opinions are more divided, the majority of the interviewees still defend that significant levels of trust and mutual aid can be found in the village. According an inhabitant of Castelo, who manages three tourism houses in the village:

One day my neighbour went to the hospital because she had a problem in her legs and she had to get treatment. I helped her, because I'm closest to her and I can watch her livestock, but other people also offered their help to keep her sheep - everyone offers their help. Because she also offers her help if someone needs it (...)
In both settlements conflict is regarded as something infrequent and not serious. However, interviewees in both villages report a reduction of the generalized trust that once could be seen in the territory, with family bonds being strengthened in detriment of community bonds.

These high levels of trust are understood as something important tourism-wise by the different tourism stakeholders in Parada: it constitutes a tourism resource for some types of tourists - namely, those who seek contact with the population or a sense of countryside character or ambiance -, it leads to the development of a climate of security for the tourists and it lubricates the functioning of tourism businesses in the settlement.

In Castelo opinions are also divided in regards with this theme, although the majority of the interviewees has also conceded that mutual aid in the community facilitates the functioning of tourism businesses. A restaurant owner in Castelo explained how trust fosters mutual help in the village in the following way:

Of course it [the high levels of trust in Castelo] helps [with the functioning of the business]! The people from the village are my clients, they promote my restaurant with tourists - what else can I ask for? (...) If a tourist wants accommodation, I have the contacts of the tourism houses and I lead them according to the amount of people and the capacity of the houses.

Both in Castelo and Parada, the relationship between tourists and residents is, generally speaking, conflict-free. However, although it was mentioned that in some cases stable relationships of friendship were created with the tourists that visit the village, it was also stated that, in general, a separation between tourists and resident population exists, despite the receptive attitude towards tourism. All interviewees agreed that tourism has no effect on trust and mutual aid levels in the area.

\section{Structural social capital}

Concerning structural social capital, the leadership and decision-making processes have great significance. The Freguesia Council 
adopts in Lindoso a unique functioning, not verified in other Portuguese freguesias: the power is divided by the three population nuclei, with each of the three members that compose the Council representing one of the villages of the freguesia. Attitudes towards this organ's actions vary, with some people describing it as a very respected entity within the village and others as an institution which has lost the people's trust. The head of the National Park's tourism office in Lindoso gave the following statement:

The Council president is a very respected person - any matter, whether private or public, can always be discussed with the Council president and the Freguesia Council. If something is not working, if there's an accessibility problem or even other problems which are not directly connected with the Council's responsibilities, the first place where people will head to solve it is the Council.

However, as a tourism academic from Parada, expert in social capital, describes:

In the past, being a member of the Council was something that lent high prestige. The president of the Council was well regarded and people had respect for him. Nowadays, the Council is not seen in the same way; this image of the "good men of the village", which existed because people deposited their trust on someone who represented the best interests of the village, has been lost somewhat. What we see now are people whose motives are not necessarily the same (...) maybe because there is more money available, maybe that's the reason (...). The trust [in the Council] that once was no longer exists (...).

Nevertheless, and despite some people's scepticism, interviewees agree that if any problems arise in the village, the most common way of solving them is still to resort to the Council's or its president's authority.

The vast majority of the interviewees said they did not know any instruments that promote the inhabitants' involvement in the decision-making process, or that they knew instruments that did not work. The latter were referring to the Freguesia Assembly, an organ in which any citizen with voting rights can participate to discuss any matters, but that observes very little (if any) attendance in their sessions. Nevertheless, it is worth of note that the residents showed no interest in deepening their participation in the decision-making process.

The relationship with the Peneda-Gerês National Park's administration is non-existent: the population is not consulted when the landuse regulation is reviewed. This regulation is, therefore, imposed on the inhabitants, generating dissatisfaction.

Associativism is led by three social, cultural and sports associations (one for each settlement), one of which - Cidadelhe's - is inactive. These associations seek to preserve the territory's traditions by organizing traditional activities, such as the traditional Carnival or the Desfolhada (the tradition of collectively taking the leaves out of the corn mazes). The activities organized by Parada's association are met with generalized, although several times passive, participation. This means that while most people enjoy the activities, only a limited amount of individuals participate in its organization, leading to feelings of frustration among the organizers. In the words of the president of the social, cultural and sports association of Parada:

In the past we didn't have a venue but we still did activities; now that we do have a venue [the association's headquarters] we barely do them anymore because the people are old and the youngsters don't care about these things; it's always the same people doing all the work (...).

The activities organized in Castelo, however, verify a more reduced participation, with it being reduced to a small group of people. These associations don't have, according to several interviewees, a role in tourism; although sometimes tourists participate in some of their activities, because they discover it by chance or because they are frequent visitors and already know them. These associations also play an important role in 
developing trust in the villages, by promoting socialization between the inhabitants.

Practices of collective action are infrequent. Activities like the above-mentioned desfolhada, once very common, are nowadays nearly inexistent outside of the association's context, and mobilization of the population to solve problems is practically non-existent. Nevertheless, the yearly maintenance of the irrigation systems and of the shepherd's cottages in the mountains are notable exceptions: still, to this day, the entire population participates in these activities.

To sum up, an abundance of unutilized social capital was found, as well as a passive and unempowered population and a tourism model which is disconnected with the population. Incidentally, two of the interviewees consider that tourism doesn't bring any kind of benefits to the village, while one tourism house owner disregards it as a secondary source of income and another one states that the exploration of his tourism houses brings her very reduced income.

Several interviewees also mention several negative points of tourism, such as the behaviour of day visitors (which leave a lot of residues without generating income), the endangerment of the villages' lifestyle and clashes between population and tourists, especially when there are large volumes of tourists. The vast majority of interviewees, however, recognize the benefits that tourism brings, with the generation of income and the increase of movement in the village being the most mentioned.

\section{Discussion and conclusion}

The conducted research has shown a tendency for a decrease in the levels of social capital in both the settlements of Castelo and Parada. This relates to social capital being a moral resource (Ostrom, 2000; Putnam, 1993): the abandonment of communitarian agriculture as a form of survival and the consequent loss of this resource's utility means it's supply suffered a reduction, favouring the strengthening of family bonds over community bonds.
However, levels of cognitive social capital are still relatively high in Lindoso, especially in Parada, where trust and mutual aid are still very much alive. In Castelo, lower levels of cognitive social capital can be perceived, although some of the interviewees have related several situations of mutual aid between the community's members. In both villages, therefore, a climate of generalized reciprocity is maintained.

Concerning structural social capital, the problems in the established leadership and decision-making processes (most of all the lack of people's interest in participating in them) are a severe debility. Associativism still thrives in Parada, although people's participation is still very passive, while in Castelo participation in associativism is limited to a reduced number of people. Although in both settlements mobilization for solving problems is reduced, practices of collective action related to agriculture and pastoralism still exist in the freguesia.

Therefore, and despite its decrease, bonding social capital is still substantially high is both settlements. In effect, it is enough to generate a climate of rivalry and even hostility between the villages in the territory. Although this rivalry has positive effects (giving a renewed impetus to the associativism in the village), it also means that low levels of bridging social capital exist between the nuclei.

Trust and mutual aid is seen as a very important factor in the territory's tourism development. On the one hand, as several interviewees referred, there is a touristic segment that seeks contact with the population, with community cohesion being seen as something important and as part of the rural attraction of the territory. On the other hand, it favours a climate of security between the inhabitants and, therefore, the tourists as well. Finally, the development of tourism businesses is boosted by the existence of this trust and mutual aid: for example, tourists often find restaurants or tourism houses because the villagers they meet indicate them.

The association's activities are made by the village's inhabitants and for the village's 
inhabitants. Nevertheless, although the majority of the interviewees referred that they believe the associations have no role tourism-wise, several persons also mentioned that associations contribute to the fomentation of socialization between the inhabitants; therefore, by stimulating confidence and mutual aid in the village, associations also have their role in stimulating tourism development. Considering this, it can be concluded that hypothesis 1 (The existence of social capital promotes rural tourism development) is confirmed.

Although it has been confirmed that social capital favours rural tourism development, the sustainability of this tourism model has not. In fact, the many negative effects mentioned by the interviewees and the fact that, according to two of them, tourism has brought no positive impacts on the territory indicate severe debilities on the implemented tourism model.

All the interviewees have rejected the idea that tourism development in Lindoso has had any impact whatsoever in terms of social capital, whether in terms of trust and self-aid, of associativism or of the general cohesion of the villages.

However, while some interviewees speak of a separation between tourists and population, a large part also described good relationships, and some even referred to the existence of friendships with those tourists. Tourism development has therefore fomented the creation of bridging social capital with individuals outside of the freguesia, although it provoked no significant impacts on bonding social capital. Consequently, it can be concluded that hypothesis 2 (Tourism development in a rural territory promotes the development of social capital) is partially confirmed, in what concerns bridging social capital.

This paper has significant ties with previous research made on social capital and tourism. It has provided support to Putnam's (1993) assertion that social capital is a moral resource, as was already mentioned. This means that due to lack of use, the supply of social capital has decreased, provoking a switch from community to family bonds that was already apparent in Fernandes' (2009) research on the Peneda-Gerês National Park. In this case, the reduction of social capital is especially worrisome for the tourism sector because, besides being important for the functioning of tourism businesses, it also functions as a tourism attraction in itself, as part of what some authors called "countryside capital": environmental, social, cultural and environmental characteristics that are unique to a certain region and make it attractive as a rural tourism destination (Macbeth, Carson, \& Northcote, 2004).

It has also provided an ideal example of a tourism model that distances itself from the population and therefore fails to provide the expected benefits, corroborating what many scholars, such as Fernandes (2009) and Park et al. (2012), had already concluded in their own research. It has furthermore proven the existence of a relationship between high levels of bonding social capital and situations of social exclusion, as Field (2008) had already concluded.

\section{Practical implications}

The results of this study are of great importance for promoting the territory's development, whose growth, vitality and progress suffered a hard blow with the evolution of society in the 20th century and with the emigration of its inhabitants. Tourism can offer, as already referred in the second section, an opportunity to develop the freguesia, to contribute to the overcoming of the aforementioned problems and to help maintaining its rich cultural and natural heritage, using social capital as the base of a tourism model that seeks an equitable distribution of benefits between all the inhabitants in the territory.

This diagnosis is thus an excellent opportunity to act on the identified problems. The development of a sustainable tourism development strategy for the territory, from a community-based perspective - as had already been proposed by Fernandes (2009) and Borlido (2016) for the entirety of the PenedaGerês National Park- seeking a deeper involvement of the inhabitants in the decision- 
making process, could promote the use of the existing social capital. It would consequently contribute to its increase, since social capital's supply, as it is a moral resource, augments with use.

On the other hand, the promotion of community agriculture activities as a tourist attraction could give a renewed impetus to associativism in the territory, promoting a closer proximity between tourists and residents and the diversification of the tourist attractions in the territory. The rivalry between settlements could also be reduced through the creation of an association network that promotes cooperation between villages for the preservation of communitarian agriculture traditions.

Awareness campaigns could also be useful in terms of promoting a larger participation in the decision-making process and in the tourism sector by the population of Lindoso, thus generalizing the benefits generated by tourism.

\section{Limitations and future research}

The realization of interviews exclusively with tourism stakeholders (the Freguesia Council and the president of the social, cultural and sports association being the exceptions) can be considered as a gap, as it does not represent a large section of the population which could show different attitudes towards touristic activity in Lindoso, since they do not see it as a source of income. This fact also means that the village of Cidadelhe was automatically excluded from the analysis, since no tourism stakeholders existed to be interviewed. One of the population nuclei in the territory is, therefore, not analysed by this study; future research could include this settlement so as to obtain a more comprehensive understanding of the area.

However, despite its limitations, this paper presents important questions and offers a basis for acting on the territory in a way that can promote its development. It also presents relevant questions that can be addressed in future studies. For example, the ways by which social capital instigates the creation of other types of capital (such as human, physical and economic capital, among others) were not explored in this paper, in the same way as it was done by McGehee et al. (2010) or Zahra \& McGehee (2013). Further research could, therefore, focus on the domino effect generated by social capital on other types of capital. On the other hand, the dynamics of the relationship between the studied villages were largely unexplored (apart from the mentioned rivalry), and further research could focus on this theme.

\section{References}

Arrow, K. J. (2000). Observations on social capital. In P. Dasgupta \& I. Serageldin (Eds.), Social capital: A multifaceted perspective (pp. 3-5). Washington D.C.: The World Bank.

Bennett, N., Lemelin, R. H., Koster, R., \& Budke, I. (2012). A capital assets framework for appraising and building capacity for tourism development in aboriginal protected area gateway communities. Tourism Management, 33(4), 752-766.

Borlido, T. (2016). Law, social capital and tourism at Peneda-Gerês: An exploratory analysis of the leadership and decisionmaking processes. Dos Algarves: $A$ Multidisciplinary E-Journal, 28, 29-44. http://doi.org/10.18089/DAMeJ.2016.28.3

Bourdieu, P. (1980). Le capital social: notes provisoires. Actes de La Recherche En Sciences Sociales, 31(2-3). Retrieved from http://www.persee.fr/web/revues/ home/prescript/article/arss_0335-

53221980 num 31_12069

Boutilier, R. (2017). Stakeholder politics: Social capital, sustainable development and the corporation. New York (NY, USA): Routledge.

Breda, Z., Costa, R., \& Costa, C. (2006). Do Clusters and Networks Make Small Places Beautiful? The Case of Caramulo (Portugal). In L. Lazzeretti \& C. S. Petrillo (Eds.), Tourism, Local Systems and Networking (pp. 67-82). Oxford: Elsevier Ltd.

Cavaco, A. (2004). Desafios de Desenvolvimento Rural: Notas de Leitura. Finisterra, XXXIX (78), 99-112. Retrieved from http://www.ceg.ul.pt/finisterra/ numeros/2004-78/78_06.pdf

Coleman, J. S. (2000a). Foundations of social theory (3rd ed.). Cambridge, MA: The 
Belknap Press of Harvard University Press.

Coleman, J. S. (2000b). Social capital in the creation of human capital. In P. Dasgupta \& I. Serageldin (Eds.), Social capital: $A$ multifaceted perspective (pp. 13-39). Washington D.C.: The World Bank.

Constituição da República Portuguesa (VII Revisão Constitucional). (2005).

Cruz, R. (2016). A escola rural na produção acadêmica portuguesa: Apontamentos sobre a (in)visibilidade de um objeto de estudo. Revista Portuguesa de Educação, 29(2), 233. http://doi.org/10.21814/rpe.9518

Direção-Geral do Território. (n.d.). Áreas das freguesias, concelhos e distritos. Retrieved 2 February 2016, from http://www.dgterritorio.pt/ficheiros/cadastr o/caop/caop_download/areasfregconcdist caop2015

Direção-Geral do Território. (2015). Mapas online. Retrieved 23 April 2017, from http://mapas.dgterritorio.pt/viewer/index.ht $\mathrm{ml}$

Durlauf, S. N. (2002). On the empirics of social capital. Economic Journal, 112(483), 459479. 0297.00079

http://doi.org/10.1111/1468

Elche-Hortelano, D., Martínez-Pérez, Á., \& García-Villaverde, P. M. (2015). Bonding capital, explotación de conocimiento e innovación incremental en los clusters de turismo cultural: las Ciudades Patrimonio de la Humanidad en España. Investigaciones Europeas de Dirección Y Economía de La Empresa, 21(3), 120128.

http://doi.org/10.1016/j.iedee.2014.03.002

Fernandes, C. de O. (2009). Community engagement with local associations and in the development of tourism: A case study of residents of three parishes in the Peneda-Gerês National Park. University of Bournemouth.

Field, J. (2008). Social Capital (2nd ed.). Abingdon: Routledge.

Figueiredo, E., Eusébio, C., \& Breda, Z. (2016). The role of local actors and rural resources in the co-creation of tourism experiences. In E. Kastenholz, M. J. Carneiro, C. Eusébio, \& E. Figueiredo (Eds.), Meeting Challenges for Rural
Tourism through Co-creation of Sustainable Tourist Experiences (pp. 155176). Newcastle upon Tyne: Cambridge Scholars Publishing.

Fontes, L. F. de O. (2011). Arqueologia, povoamento e construção de paisagens serranas. O Termo de Lindoso, na Serra Amarela. Universidade do Minho. Retrieved from http://hdl.handle.net/1822/20982

Fortescu, T. de. (2016). Fighting Depopulation in Moutain areas: Revitalization Dynamics and Strategies in the Alpujarra Granadina (Andalusia). Space Populations Societies, (2015/3-2016/1).

http://doi.org/10.4000/eps.6149

Fundação Francisco Manuel dos Santos. (n.d.). O que são NUTS? Retrieved 29 October 2015, from http://www.pordata.pt/O+que+sao+NUTS

Galvão, M. J., \& Devy-Vareta, N. (2010). A multifuncionalidade das paisagens rurais: uma ferramenta para o desenvolvimento. Cadernos: Curso de Doutoramento Em Geografia, 2. Retrieved from https://repositorio-

aberto.up.pt/bitstream/10216/25322/2/nico ledevyvareta000100034.pdf

Gibson, H. J., Walker, M., Thapa, B., Kaplanidou, K., Geldenhuys, S., \& Coetzee, W. (2014). Psychic income and social capital among host nation residents:

A pre-post analysis of the 2010 FIFA World Cup in South Africa. Tourism Management, 44, 113-122.

Hanifan, L. J. (1916). The rural school community center. The Annals of the American Academy of Political and Social Science, 67, 130-138. Retrieved from http://www.jstor.org/stable/1013498

Huang, W.-J., Beeco, J. A., Hallo, J. C., \& Norman, W. C. (2016). Bundling attractions for rural tourism development. Journal of Sustainable Tourism, 24(10), 1387-1402.

http://doi.org/10.1080/09669582.2015.111 5510

Instituto Nacional de Estatística. (2014). População residente em 2001 e 2011, segundo os grupos etários e sua evolução entre 2001 e 2011. Retrieved 19 March 2016, from http://www.ine.pt/investiga dores/Quadros/Q102.zip 
Social capital as cause and consequence of rural touristic development: The case of Lindoso (Portugal).

Jones, S. (2005). Community-Based Ecotourism. Annals of Tourism Research, 32(2), 303-324. http://doi.org/10.1016/j. annals.2004.06.007

Karlsson, S.-E. (2005). The Social and the Cultural Capital of a Place and their Influence on the Production of Tourism A Theoretical Reflection based on an Illustrative Case Study. Scandinavian Journal of Hospitality and Tourism, 5(2), 102-115. http://doi.org/10.1080/150222 50510014408

Kastenholz, E., \& Sparrer, M. (2009). Rural dimmensions of the commercial home. In P. Lynch, A. Mclntosh, \& H. Tucker (Eds.), Commercial Homes in Tourism: An International Perspective (pp. 138-150). Abingdon: Routledge.

Keane, M. (2000). Rural Tourism and Rural Development. In H. Briassoulis \& J. van der Straaten (Eds.), Tourism and the Environment: Regional, Economic and Policy Issues (2nd ed., pp. 107-122). Dordrecht (Nederland): Springer Science+Business Media.

Krishna, A., \& Shrader, E. (2000). CrossCulture Measures of Social Capital: A Tool and Results from India and Panama. Social Capital Initiative Working Paper No. 21. Washington D.C.: World BANK.

Macbeth, J., Carson, D., \& Northcote, J. (2004). Social Capital, Tourism and Regional Development: SPCC as a Basis for Innovation and Sustainability. Current Issues in Tourism, 7(6), 502-522. http: //doi.org/10.1080/1368350050408668200

Mansuri, G., \& Rao, V. (2004). CommunityBased and -Driven Development: A Critical Review. The World Bank Research Observer, 19(1), 1-39. http://doi.org/10.1093/wbro/lkh012

Martínez-Pérez, Á., García-Villaverde, P. M., \& Elche, D. (2016). The mediating effect of ambidextrous knowledge strategy between social capital and innovation of cultural tourism clusters firms. International Journal of Contemporary Hospitality Management, 28(7), 14841507. http://doi.org/10.1108/IJCHM-082014-0405

Mbaiwa, J. E., \& Stronza, A. L. (2010). The effects of tourism development on rural livelihoods in the Okavango Delta,
Botswana. Journal of Sustainable Tourism, 18(5), 635-656. http://doi.org/10. 1080/09669581003653500

McCool, S. F., \& Martin, S. R. (1994). Community Attachment and Attitudes Toward Tourism Development. Journal of Travel Research, 32(3), 29-34. http: //doi.org/10.1177/004728759403200305

McGehee, N. G., Lee, S., O'Bannon, T. L., \& Perdue, R. R. (2010). Tourism-related Social Capital and Its Relationship with Other Forms of Capital: An Exploratory Study. Journal of Travel Research, 49(4), 486-500. http://doi.org/10.1177/004728 7509349271

McIntyre, G. (1993). Sustainable tourism development: guide for local planners. Madrid: World Tourism Organization.

Möller, P., \& Amcoff, J. (2016). Tourism's localised population effect in the rural areas of Sweden. Scandinavian Journal of Hospitality and Tourism, $0(0), 1-17$. http:// doi.org/10.1080/15022250.2016.1259584

Muilu, T., Gilbert, A., Phimister, E., \& Shucksmith, M. (2017). The changing rural context. In B. Jentsch \& M. Shucksmith (Eds.), Young People in Rural Areas of Europe (2nd ed., pp. 26-62). New York (NY, USA): Routledge.

Negi, J. (1990). Tourism Development and Resource Conservation. New Delhi: Metropolitan Book Company.

Nunes, A., Lourenço, L., Bento-Gonçalves, A., \& Vieira, A. (2013). Três décadas de incêndios florestais em Portugal: incidência regional e principais fatores responsáveis. Cadernos de Geografia, 32, 133-143.

Ostrom, E. (2000). Social capital: a fad or fundamental concept? In P. Dasgupta \& I. Serageldin (Eds.), Social capital: A multifaceted perspective (pp. 172-214). Washington D.C.: The World Bank.

Page, S., \& Getz, D. (1997). The Business of Rural Tourism: International Perspectives. In S. Page \& D. Getz (Eds.), The Business of Rural Tourism: International Perspectives (pp. 3-37). Filey: International Thomson Publishing.

Park, D.-B., Lee, K.-W., Choi, H.-S., \& Yoon, Y. (2012). Factors influencing social capital in rural tourism communities in South Korea. Tourism Management, 33(6), 
1511-1520. $\quad$ http://doi.org/10.1016/j. tourman.2012.02.005

Pato, L., Breda, Z., Cunha, C., \& Kastenholz, E. (2014). Experiência turística rural vivida e cocriada pelos agentes da oferta e de planeamento. In E. Kastenholz, C. Eusébio, E. Figueiredo, M. J. Carneiro, \& J. Lima (Eds.), Reinventar o Turismo Rural em Portugal: Cocriação de experiências turísticas sustentáveis (pp. 107-124). Aveiro: UA Editora.

Pillai, K. G., Hodgkinson, G. P., Kalyanaram, G., \& Nair, S. R. (2017). The Negative Effects of Social Capital in Organizations:

A Review and Extension. International Journal of Management Reviews, 19(1), 97-124. http://doi.org/10.1111/ijmr.12085

Pongponrat, K., \& Chantradoan, N. J. (2012). Mechanism of social capital in community tourism participatory planning in Samui Island, Thailand. Tourismos, 7(1), 339-349.

Portes, A. (1998). Social Capital: Its Origins and Applications in Modern Sociology. Annual Review of Sociology, 24, 1-24. Retrieved from http://www.jstor.org/stable /223472

Putnam, R. D. (1993). Making Democracy Work: Civic Traditions in Modern Italy. Princeton, NJ: Princeton University Press.

Putnam, R. D. (1995). Bowling Alone: America's Declining Social Capital. Journal of Democracy, January, 65-78. Retrieved from http://archive.realtor.org/ sites/default/files/BowlingAlone.pdf

Putnam, R. D. (2000). Bowling Alone: the collapse and revival of American society. New York, NY: Touchstone.

Quivy, R., \& Campenhoudt, L. Van. (2013). Manual de Investigação em Ciências Sociais (6th ed.). Lisboa: Gradiva.

Rebelo, D. G. V. da S. (2012). The role of social relationships in the setting up and management of small tourism businesses in two portuguese rural areas. University of Bournemouth.

Ribeiro, M., \& Marques, C. (2002). Rural tourism and the development of less favoured areas - between rhetoric and practice. International Journal of Tourism Research, 4(3), 211-220. http://doi.org/ 10.1002/jtr.377
Saxena, G., Clark, G., Oliver, T., \& Ilbery, B. (2007). Conceptualizing Integrated Rural Tourism. Tourism Geographies, 9(4), 347-370. http://doi.org/10.1080/1461668 0701647527

Silva, R. (2007). Municípios e Desenvolvimento Local em Regiões de Baixa Densidade. In III Congresso de Estudos Rurais - Painel 3 (pp. 20-21). Faro: Sociedade Portuguesa de Estudos Rurais \& Universidade do Algarve. Retrieved from http://sper.pt/oldsite/IIICER/Resumos/ 5_LivroDeResumos_3CER_Painel3.pdf

Terres, J. M., Nisini, L., \& Anguiano, E. (2013). Assessing the risk of farmland abandonment in the EU. Retrieved 8 December 2015, from http://ec.europa.eu/ agriculture/external-tudies/2013/farmlandabandonment/fulltext_en.pdf

Uphoff, N. (2000). Understanding social capital: learning from the analysis and experience of participation. In P. Dasgupta \& I. Serageldin (Eds.), Social capital: $A$ multifaceted perspective (pp. 215-249). Washington D.C. (USA): The World Bank.

Woolcock, M., \& Narayan, D. (2000). Social Capital: Implications for Development theory and policy. The World Bank Research Observer, 15(2), 225-249. http://doi.org/10.1093/wbro/15.2.225

World Commission on Environment and Development. (1987). Report of the World Commission on Environment and Development: Our Common Future. Retrieved 1 December 2017, from http://www.un-documents.net/ourcommon-future.pdf

Zahra, A., \& McGehee, N. G. (2013). Volunteer Tourism: A Host Community Capital Perspective. Annals of Tourism Research, 42(2006), 22-45. http://doi.org/10.1016/j. annals.2013.01.008

Zhao, W., Ritchie, J. R. B., \& Echtner, C. M. (2011). Social capital and tourism entrepreneurship. Annals of Tourism Research, 38(4), 1570-1583. http://doi. org/10.1016/j.annals.2011.02.006 